\title{
A rapid colorimetric method for the estimation of urinary chlorides
}

\author{
R. A. CROCKSON \\ From the Department of Experimental Pathology, University of Birmingham
}

SYNOPSIS A rapid and reproducible method for chloride estimation in urine is described. The colour produced is stable and obeys Beer's law over a wide range of concentrations using a simple colorimeter and filter. The method gives good agreement with both the potentiometric titration method of Sanderson (1952) and the mercurimetric titration method of Schales and Schales (1941). The precision of the colorimetric method, though inferior to that of the potentiometric method, is similar to that of the mercurimetric method.

In a review of the available colorimetric procedures for chloride estimation (MacDonald, 1960) it was suggested that the mercuric thiocyanate and ferric chloride methods were the most suitable. The mercuric thiocyanate method appears to be better suited to biological materials containing protein; it was first described by Iwasaki, Utsumi, and Ozawa (1952) and depends upon the fact that mercuric thiocyanate is so feebly dissociated that insufficient thiocyanate ions are liberated to give the characteristic colour with iron (III). On the addition of chloride, however, a soluble mercuric chloride complex is preferentially formed and the thiocyanate ions thus displaced form an orange colour with ferric salts. In aqueous solutions the colour formed does not obey Beer's law, but, when formed in suitable concentrations of dioxan, it gives a linear relation over a wide range of chloride concentrations (Iwasaki, Utsumi, Hageno, and Ozawa, 1956).

The following method has been developed for use with urines; other fluids were measured to test the range of application for the method.

METHODS

1 COLORIMETRIC METHOD For this method the following reagents were made up.

Iron alum solution Ammonium ferric sulphate (AnalaR), $3 \mathrm{~g}$., per $100 \mathrm{ml}$. in a saturated aqueous solution of sulphamic acid.

Mercuric thiocyanate solution Mercuric thiocyanate $100 \mathrm{mg} . / 100 \mathrm{ml}$. dioxan (AnalaR): ethanol (9:1).

Chloride standard Dried sodium chloride (AnalaR), $5 \cdot 38$ g. per litre $\equiv 100 \mathrm{mEq} / 1$.

Received for publication 22 March 1963.
Procedure Into a 5 in. $\times \frac{5}{8}$ in. test tube pipette $3.0 \mathrm{ml}$. of the iron alum solution. Add $0.05 \mathrm{ml}$. of the sample urine from a 'to contain' pipette. Add $3.0 \mathrm{ml}$. of the mercuric thiocyanate solution and immediately mix the contents of the tube. Prepare a standard and a reagent blank in the same way using $\mathbf{0 . 0 5} \mathrm{ml}$. of either the chloride standard or distilled water.

Measure the extinction of the tests, the standard, and the reagent blank in an E.E.L. portable photoelectric colorimeter against a water blank using an Ilford 622 filter.

Calculation This is done by the equation

Extinction of test - extinction of reagent blank Extinction of standard - extinction of reagent blank $\times$

$$
100=\mathrm{C1}^{-} \mathrm{mEq} / 1 \text {. }
$$

2 POTENTIOMETRIC TITRATION This method was used as described by Sanderson (1952) using $0.2 \mathrm{ml}$. of sample.

3 MERCURIMETRIC TITRATION This method was used as described by Schales and Schales (1941) using $0.2 \mathrm{ml}$. of sample.

In all methods the same sodium chloride standard ( $\left.\equiv 100 \mathrm{mEq} / 1 \mathrm{C1}^{-}\right)$was used.

\section{RESULTS}

Using a Unicam SP 700 recording spectrophotometer it was confirmed that the end product formed in the colorimetric method has an absorption maximum at $460 \mathrm{~m} \mu$; the colour was found to be stable for more than one hour at room temperature, and reached the maximum intensity in less than 30 seconds. The final colour intensity was found to increase as the concentrations of either the mercuric thiocyanate or the ferric ammonium sulphate increased, and to decrease with rise in $p \mathrm{H}$. 
The concentrations of mercuric thiocyanate and ferric ammonium sulphate used are chosen to give maximum colour intensity, the mercuric thiocyanate concentration being near to saturation. Sulphamic acid was chosen to give a low $p \mathrm{H}(0.65)$ and caused protein to become denatured and soluble. It has been found unnecessary to include a sample blank to allow for pigment interference, in view of the considerable dilution of the sample (approximately 1/100). In this method chloride concentrations between 10 and $160 \mathrm{mEq} / \mathrm{l}$. give a straight line relation with extinction. A non-linear relation is found if the contents of the tube are not mixed immediately.

Chloride estimations have been performed in duplicate on 106 samples by all three methods. Seventy-four urines were chosen so as to test the effect of both high and low chloride concentrations: ileostomy fluids (20), gastric aspirates (11), and bile (1) were included to assess the effect of pigments on the colorimetric method.

\section{DISCUSSION}

From the duplicate results obtained by each of the three methods the mean and the standard deviation have been calculated for each method (Table I).

\section{TABLE I}

SUMMARY OF RESULTS OBTAINED BY DUPLICATE ESTIMATIONS OF CHLORIDE ON 106 SAMPLES BY EACH OF THREE METHODS USED

\begin{tabular}{|c|c|c|c|}
\hline \multirow[t]{2}{*}{ Method } & \multirow{2}{*}{$\begin{array}{l}\text { Range } \\
\text { Encountered }\end{array}$} & \multicolumn{2}{|c|}{ Calculated } \\
\hline & & Mean & $\begin{array}{l}\text { Standard Deviation } \\
\text { of Method }\end{array}$ \\
\hline $\begin{array}{l}\text { Mercurimetric } \\
\text { Potentiometric } \\
\text { Colorimetric }\end{array}$ & $\begin{array}{l}2-155 \\
3-151 \\
2-156\end{array}$ & $\begin{array}{l}57 \cdot 5 \\
57 \cdot 4 \\
57 \cdot 7\end{array}$ & $\begin{array}{l}2 \cdot 22 \\
0 \cdot 94 \\
2 \cdot 35\end{array}$ \\
\hline
\end{tabular}

All values are expressed in mEq. $\mathrm{Cl}^{-} / 1$.

From Table II it can be seen that there is no significant difference between the means $(P>0.02$ in all cases) and that there is good correlation between the three methods $(P<0.001)$. However, the potentiometric method has a significantly smaller variance than either of the other two methods $(\mathbf{P}<0.001)$; there is no significant difference between the variance of the colorimetric and mercurimetric methods $(P=0 \cdot 2)$.

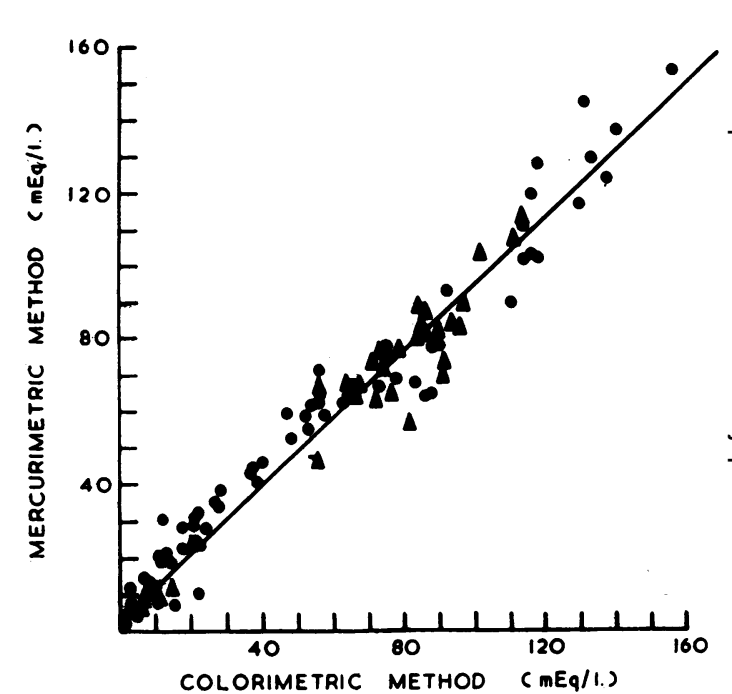

FIG. 1. Comparison of the results obtained with the proposed colorimetric method and the mercurimetric titration method on 106 samples.

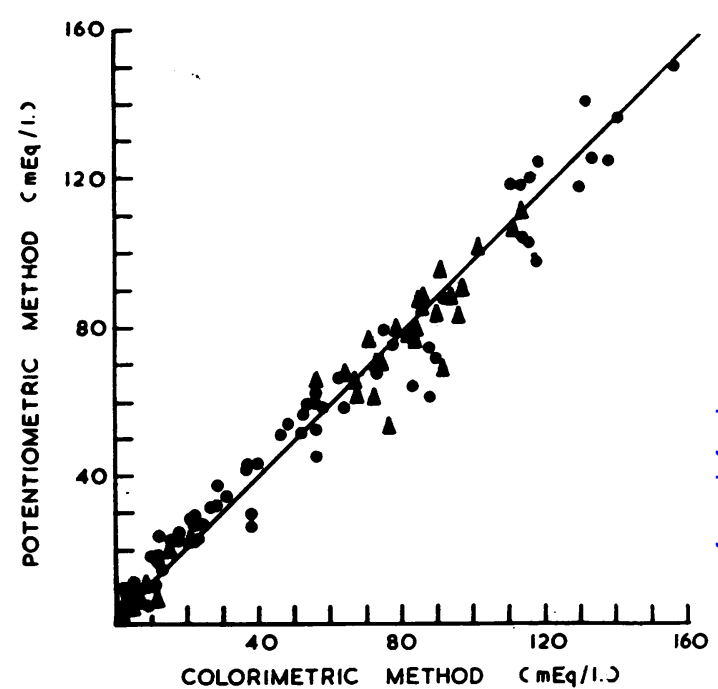

FIG. 2. Comparison of the results obtained with the proposed colorimetric method and the potentiometric titration $\overline{\mathrm{N}}$ method on 106 samples. $=$ urines. $\Delta=$ other biological $\Omega$ fluids. The line shown is the calculated functional regression $N$ line.

TABLE II

CORRELATION BETWEEN COLORIMETRIC AND TITRIMETRIC METHODS

\begin{tabular}{|c|c|c|c|c|c|c|}
\hline \multirow[t]{2}{*}{ Methods } & \multicolumn{2}{|c|}{ Correlation } & \multicolumn{2}{|c|}{ Comparison of Variances } & \multicolumn{2}{|c|}{ Comparison of Means } \\
\hline & $\boldsymbol{r}$ & $\boldsymbol{P}$ & $\boldsymbol{F}$ & $\boldsymbol{P}$ & $t$ & $\boldsymbol{P}$ \\
\hline $\begin{array}{l}\text { Colorimetric/mercurimetric } \\
\text { Colorimetric/potentiometric } \\
\text { Mercurimetric/potentiometric }\end{array}$ & $\begin{array}{l}0.98 \\
0.98 \\
0.99\end{array}$ & $\begin{array}{l}<0.001 \\
<0.001 \\
<0.001\end{array}$ & $\begin{array}{l}1 \cdot 12 \\
5 \cdot 85 \\
5 \cdot 23\end{array}$ & $\begin{aligned} & 0.2 \\
< & 0.001 \\
< & 0.001\end{aligned}$ & $\begin{array}{l}0 \cdot 83 \\
1 \cdot 21 \\
0 \cdot 42\end{array}$ & $\begin{array}{l}>0.2 \\
>0.2 \\
>0.2\end{array}$ \\
\hline
\end{tabular}


From Figures 1 and 2 it can be seen that the colorimetric method gives good agreement with the two standard methods over the range of chloride concentrations encountered; the line shown in each of these figures is the functional regression line calculated by the method used by Blainey and Squire (1960).

These calculations suggest that the potentiometric method is the most precise of the three methods used, the other two methods being equal to one another in precision. When duplicate estimations are performed all three methods give similar final results. Bile and other pigments do not appear to influence the colorimetric method more than either of the other two methods.
In its present form this method does not appear to be suitable for use with whole serum.

My thanks are due to Professor R. Belcher, Professor H. E. Daniels, Professor J. R. Squire, and Mr. J. J. Sexton for their advice and interest, and to Miss A. P. Ratcliff for skilled technical assistance.

\section{REFERENCES}

Blainey, J. D., and Squire, J. R. (1960). Clin. Sci., 19, 287.

Iwasaki, I., Utsumi, S., Hageno, K., and Ozawa, T. (1956). Bull. Chem. Soc. Japan, 29, 860.

- - and Ozawa, T. (1952). Ibid., 25, 226.

MacDonald, A. M. G. (1960). Industr. Chem., 36, 241

Sanderson, P. H. (1952). Biochem. J., 52, 502.

Schales, O., and Schales, S. S. (1941). J. biol. Chem., 140, 879.

\section{Broadsheets prepared by the Association of Clinical Pathologists}

The following broadsheets (new series) are published by the Association of Clinical Pathologists. They may be obtained from Dr. R. B. H. Tiemey, Pathological Laboratory, Boutport Street, Barnstaple, N. Devon. The prices include postage, but airmail will be charged extra.

3 The Detection of Barbiturates in Blood, Cerebrospinal Fluid, Urine, and Stomach Contents. 1953. L. C. NICKOLLS. 1s.

4 The Estimation of Carbon Monoxide in Blood. 1953. D. A. STANLEY. 1s.

5 The Identification of Reducing Substances in Urine by Partition Chromatography on Paper. 1953. G. B. MANNING. $1 \mathrm{~s}$.

6 The Paul-Bunnell Test. 1954. R. H. A. SWaIN. 1s.

7 The Papanicolaou Technique for the Detection of Malignant Cells in Sputum. 1955. F. HAMPSON. 1s.

13 The Identification of Serotypes of Escherichia coli Associated with Infantile Gastro-enteritis. 1956. JOAN TAYLOR. $1 \mathrm{s.}$

14 The Determination of Serum Iron and Serum Unsaturated Iron-binding Capacity. 1956. ARTHUR JORDAN. 1s.

16 Preservation of Pathological Museum Specimens. 1957. L. W. PROGER. 1s.

17 Cultural Diagnosis of Whooping-cough. 1957. B. W. LACEY. 1s.

20 Investigation of Porphyrin/Porphyria. 1958 (reprinted 1962). C. RIMINGTON. 2s.

23 The Dried Disc Technique for Bacterial Sensitivity Tests. 1959. R. W. FAIRBROTHER and J. C. SHERRIS. 1s.

24 Safe Handling of Radioactive Tissues in the Laboratory and Post-mortem Room. 1959. R. c. CURRAN. $1 \mathrm{~s}$.

26 The Periodic Acid-Schiff Reaction. 1959. A. G. E. PEARSE 1s.

28 Daily Fatty Acid Excretion. 1960. A. C. FRAZER. $2 s$.

29 The Preparation of Bone for Diagnostic Histology. 1960. D. H. Collins. 2s.

30 Control of Accuracy in Chemical Pathology. 1961. G. H. GRANT. 4s.
31 Investigation of Haemorrhagic States with Special Reference to Defects of Coagulation of the Blood. 1961. E. K. BLACKBURN. 4s.

32 Detection of Resistance to Streptomycin, P.A.S., and Isoniazid in Tubercle Bacilli. 1961. R. CRUICKSHANK and $\mathbf{s}$. M. STEWART. $2 \mathrm{~s}$.

33 The Laboratory Detection of Abnormal Haemoglobins. 1961. H. LeHMANN and J. A. M. AGER. 4s.

34 Titration of Antistreptolysin O. 1961. H. GOODER and R. E. O. WILLIAMS. 2s.

35 The Estimation of Faecal 'Urobilinogen'. 1961. C. H. GRAY. 2 s.

36 Quantitative Determination of Porphobilinogen and Porphyrins in Urine and Faeces. 1961. C. RIMINGTON. 3s. 6d.

37 The Paper Electrophoresis of Serum and Urinary Proteins. 1961. G. FRANGLEN and N. H. MARTIN. 4s.

38 The Augmented Histamine Gastric Function Test. 1961. M. LUBRAN. 2s.

39 Investigation of Haemolytic Anaemia. 1961. J. G. SELWYN. $2 s$.

40 Short-term Preservation of Bacterial Cultures. 1962. E. JOAN STOKES. 2s.

41 Serological Tests for Syphilis. 1962. A. E. WILKINSON. 6s.

42 The Determination of Glucose 6-Phosphate Dehydrogenase in Red Cells. 1962. T. A. J. PRANKERD. $2 s$.

43 Mycological Techniques. 1962. R. W. RIDDELL. 3s. 6 d.

44 The Laboratory Investigation of Catecholamine Secreting Tumours. 1963. M. SANDLER and C. R. J. RUTHVEN. 2s.

45 Diagnostic Test for Hereditary Galactosaemia. 1963. v. SCHWARZ. 2 s. 